\title{
Utilization of Microsoft Office 365 at Jatiluhur 3 Elementary School
}

\section{Dwi Purwanti}

SD Negeri 3 Jatiluhur dpurwanti1976@gmail.com

Article History

accepted 14/11/2020

approved 21/11/2020

published 26/11

\begin{abstract}
The pandemic that hit the country of Indonesia brought changes in all sectors. Including the world of education. Face-to-face learning is forced to shift to distance learning. This is a challenge for educators and students. Especially for educators, creativity is required in distance learning. The pandemic that occurred in the 21st century demands that teachers be more professional, must not be blind to technology, and must be able to apply and adapt technology in learning. The fact is that not all teachers are technology literate. Therefore it is necessary to conduct training or increase in technology-based teaching competencies. The focus of this study is: 1) The concept and function of Microsoft office 365 in learning; (2) the use of Microsoft Forms and Sway in teaching at Jatiluhur 3 elementary school. The results of the study include: (1) Microsoft Office 365 has various features that are very supportive of learning; (2) The six teachers at Jatiluhur 3 elementary school have used Microsoft Office 365 with the Microsoft form and sway features.
\end{abstract}

Keywords: Microsoft Office, elementary school teachers

\begin{abstract}
Abstrak
Pandemi yang melanda negara Indonesia membawa perubahan dalam semua sektor. Termasuk dunia pendidikan. Pembelajaran tatap muka dipaksa harus beralih ke pembelajaran jarak jauh. Hal ini menjadi tantangan bagi pendidik dan peserta didik. Terutama bagi pendidik, dituntut kreativitas dalam pembelajaran jarak jauh. Pandemi yang terjadi pada abad 21 menuntut guru untuk lebih professional, tidak boleh buta terhadap teknologi, dan harus mampu mengaplikasikan dan mengadaptasi teknologi dalam pembelajaran. Fakta yang terjadi belum semua guru melek terhadap teknologi. Oleh karena itu perlu dilakukan pelatihan atau peningkatan kompetensi mengajar berbasis teknologi. Fokus kajian ini berupa: 1) Konsep dan fungsi Microsoft office 365 dalam pembelajaran; (2) pemanfaatan Microsoft Forms dan Sway dalam pembelajaran di SD Negeri 3 Jatiluhur. Hasil kajian antara lain: (1) Microsoft Office 365 memiliki berbagai fitur yang sangat menunjang dalam pembelajaran.; (2) Pemanfaatan Microsoft Office 365 yang telah dilakukan oleh enam guru di SD Negeri 3 Jatiluhur adalah fitur Microsoft form dan sway.
\end{abstract}

Kata kunci: Microsoft Office, guru sekolah dasar

Social, Humanities, and Education Studies (SHEs): Conference Series https://jurnal.uns.ac.id/shes

p-ISSN 2620-9284

e-ISSN 2620-9292 


\section{PENDAHULUAN}

Pertengahan Maret 2020, kondisi pendidikan di Indonesia mengalami perubahan. Hal ini diperkuat dengan Surat Edaran Gubernur Jawa Tengah Nomor : 420/0005956 tanggal 15 Maret 2020 tentang Pencegahan Penyebaran Corona Virus Disease (Covid-19). Tepat pada tanggal 16 Maret 2020 semua sekolah secara serempak dipaksa melakukan pembelajaran jarak jauh. Hal ini disebabkan pandemi Covid-19 yang menyerang Indonesia. Penularan Covid-19 yang secara cepat harus diputus mata rantainya. Diantaranya adalah dengan menjaga jarak dan tidak mengadakan kerumunan. Sekolah sebagai salah satu tempat kegiatan yang cukup intens melakukan kontak fisik terkena imbasnya. Kegiatan pembelajaran yang semula dilaksanakan secara tatap muka langsung, beralih menjadi belajar dari rumah.

Sebagaimana kita ketahui bahwa keberhasilan pembangunan negara salah satu tolak ukurnya adalah keberhasilan pendidikan. Melalui pendidikan akan melahirkan generasi penerus yang cerdas intelektual maupun emosional, terampil, dan mandiri untuk mencapai pembangunan. Tantangan yang dirasa berat oleh pendidik dan peserta didik di masa pandemi. Terutama bagi pendidik, dituntut kreativitas dalam penyampaian materi pelajaran tidak bisa bertatap jika secara langsung.

Pembelajaran secara daring (dalam jaringan) atau virtual menjadi alternatif. Zhafira (2020), menjelaskan bahwa terdapat model pembelajaran lain yang bisa digunakan oleh tenaga pengajar sebagai media penyampaian ilmu pengetahuan, yaitu pembelajaran daring dan pembelajaran campuran (kombinasi dari dua metode pembelajaran yaitu tatap muka dan pembelajaran daring). Metode pembelajaran daring tidak menuntut siswa untuk hadir di kelas. Siswa dapat mengakses pembelajaran melalui media internet.

Kita sebagai pendidik harus mempunyai pola pikir yang positif terhadap perubahan pembelajaran. Tetap memberikan pembelajaran yang berkualitas meskipun tidak bertemu secara langsung dengan siswa. Membuat inovasi pembelajaran sehingga anak tetap tertarik dan semangat dalam belajar. Belajar teknologi menjadi kewajiban supaya tidak tenggelam.

Pandemi Covid-19 ini bisa dikatakan sebagai wujud nyata penerapan teknologi dalam pembelajaran. Hal ini sesuai dengan pendapat Makagiansar (1996) bahwa pada abad ke-21 sistem pendidikan akan mengalami pergeseran atau perubahan paradigma, diantaranya adalah kampanye buta aksara ke kampanye buta teknologi, budaya, dan komputer. Sedangkan menurut Surya (1998) salah satu karakteristik pembelajaran pada abad ke-21 adalah penggunaan berbagai inovasi IPTEK terutama media elektronik, informatika, dan komunikasi dalam berbagai kegiatan pendidikan.

Keberadaan seorang guru pada abad ke-21 dituntut harus lebih professional. Guru harus dapat mengintegrasikan teknologi informasi dan komunikasi. Sejalan dengan pernyataan Wartomo (2016), kompetensi guru harus diorientasikan terhadap perkembangan teknologi informsasi dan komunikasi dan masyarakat digital dewasa ini. Aplikasi dan adaptasi teknologi dalam ruang-ruang pembelajaran menjadi sebuah keharusan dalam menghadapi perubahan di abad 21.

Mendasari berbagai pendapat di atas dapat disimpulkan bahwa pendidikan yang terjadi pada abad 21 menuntut guru untuk lebih professional, tidak boleh buta terhadap teknologi, dan harus mampu mengaplikasikan dan mengadaptasi teknologi dalam pembelajaran. Namun fakta yang terjadi belum semua guru melek terhadap teknologi. Mereka baru sadar akan pentingnya teknologi dalam pembelajaran ketika pandemi melanda. Oleh karena itu perlu dilakukan pelatihan atau peningkatan kompetensi mengajar berbasis teknologi. 
Seperti yang telah dilakukan oleh guru-guru di SD Negeri 3 Jatiluhur. Berbagai pelatihan penggunaan teknologi telah diikuti, diantaranya adalah pelatihan pemanfaatan aplikasi Microsoft Office 365 yaitu fitur Microsotf Forms dan sway. Pelatihan Microsoft Office 365 yang telah mereka peroleh diaplikasikan dalam pembelajaran di masa pandemi ini.

Suprianto (2018) Office 365 adalah perangkat lunak online yang dibuat oleh microsoft untuk kebutuhan pengguna di perkantoran, dunia bisnis maupun pendidikan. Khusus dalam dunia pendidikan microsoft memberikan secara gratis kepada pengguna office 365 dan dengan beberapa fitur yang dimiliki dapat digunakan sebagai e-learning. Platform ini tidak hanya menyediakan fiturfitur yang lazim digunakan oleh guru pada saat mengajar, namun juga untuk manajemen sekolah secara keseluruhan, Microsoft 365 merupakan salah satu aplikasi yang bisa digunakan oleh guru dalam pembelajaran jarak jauh.

Keuntungan dari aplikasi ini adalah lebih mudah dan simple. Dengan user interface yang mudah. selain itu manfaat dari penggunaan Microsoft Office 365 adalah memberikan efisiensi kerja dan meningkatkan produktivitas dalam pekerjaan. Manfaat-manfaat tersebut bisa didapat dari fitur Microsoft Forms, Sway, dan sebagainya. Berdasarkan uraian tersebut maka dalam kajian ini akan dibahas tentang pemanfaatan Microsoft office 365 di SD Negeri 3 Jatiluhur. Fokus kajian ini berupa: 1) Konsep dan fungsi Microsoft office 365 dalam pembelajaran; (2) pemanfaatan Microsoft Forms dan Sway dalam pembelajaran di SD Negeri 3 Jatiluhur..

\section{HASIL DAN PEMBAHASAN}

1. Konsep dan Fungsi Microsoft Office 365

Microsoft Office 365 adalah aplikasi terbaru yang bertujuan untuk mempermudah dalam berkomunikasi. Microsoft Office 365 merupakan Software as a Service (SaaS) yang memungkinkan penggunanya untuk mengakses email, dokumen, kontak, kalender, dan berkolaborasi di mana saja dengan menggunakan berbagai perangkat seperti: PC, laptop, tablet, atau smartphone (Ferdiana, Eka, \& Fauzan, 2013). Untuk instansi pendidikan seperti sekolah dan perguruan tinggi produk ini tidak dipungut biaya (Microsoft, 2017).

Microsoft Office 365 memiliki berbagai fitur yang sangat menunjang dalam pembelajaran.Beberapa fitur tersebut diantaranya adalah Microsoft Forms dan sway. Microsoft forms terdiri dari angket dan kuis. Forms angket biasa digunakan untuk melakukan presensi online, pengumpulan data atau jajak pendapat. Sedangkan forms kuis digunakan sebagai pembuatan bank soal yang dibuat sendiri oleh guru ataupun bank soal yang dibagikan oleh guru lainnya. Dengan menggunakan kuis, guru dapat secara langsung melakukan penilaian secara digital dan menyimpan hasilnya secara digital juga. Penggunaan form ini akan memudahkan guru dengan mengurangi beban administrasi berbasis kertas. Fitur Sway berfungsi sebagai media pembuatan buku digital. Materi pelajaran dapat dibuka oleh siswa melalui link sway yang dikirim oleh guru.

2. Pemanfaatan Microsoft Office 365

\section{a. Microsoft Forms}

Microsoft Forms adalah salah satu bagian dari Office 365 yang memungkinkan guru dan siswa untuk dengan cepat dan mudah membuat formulir dan kuis. Guru membuat formulir atau kuis, lalu mengundang orang lain untuk mengisinya menggunakan tautan yang dibagikan yang dapat diakses melalui browser dan perangkat apa pun. Perancangan pembuatan forms angket 
dan kuis dilakukan dengan berbagai pengaturan diantaranya pengaturan waktu pengisian, pengaturan soal dan score. Siswa hanya dapat membuka atau mengisi pada waktu yang telah disetting oleh guru pada forms.

Berdasarkan angket yang telah disebar kepada enam guru di SD Negeri 3 Jatiluhur tentang pemanfaatan Microsoft office 365 , guru A, B, C, D, E, dan F menyatakan bahwa mereka telah memanfaatkan Microsoft Office 365. Pemanfaatan fitur Microsoft form digunakan sebelum melakukan pembelajaran. Microsoft form dimanfaatkan untuk melakukan presensi online kapada siswa. Guru membuat forms yang berupa daftar isian tentang kehadiran siswa, dimulai dari nama dan kelas. Guru mengirimkan link forms presensi pada pagi hari untuk diisi oleh siswa. Kemudian siswa mengisi link tersebut. Hasil dari pengisian forms akan terkirim kembali kepada guru. Berikut adalah tampilan forms presensi yang telah dibuat oleh guru di SD Negeri 3 Jatiluhur.

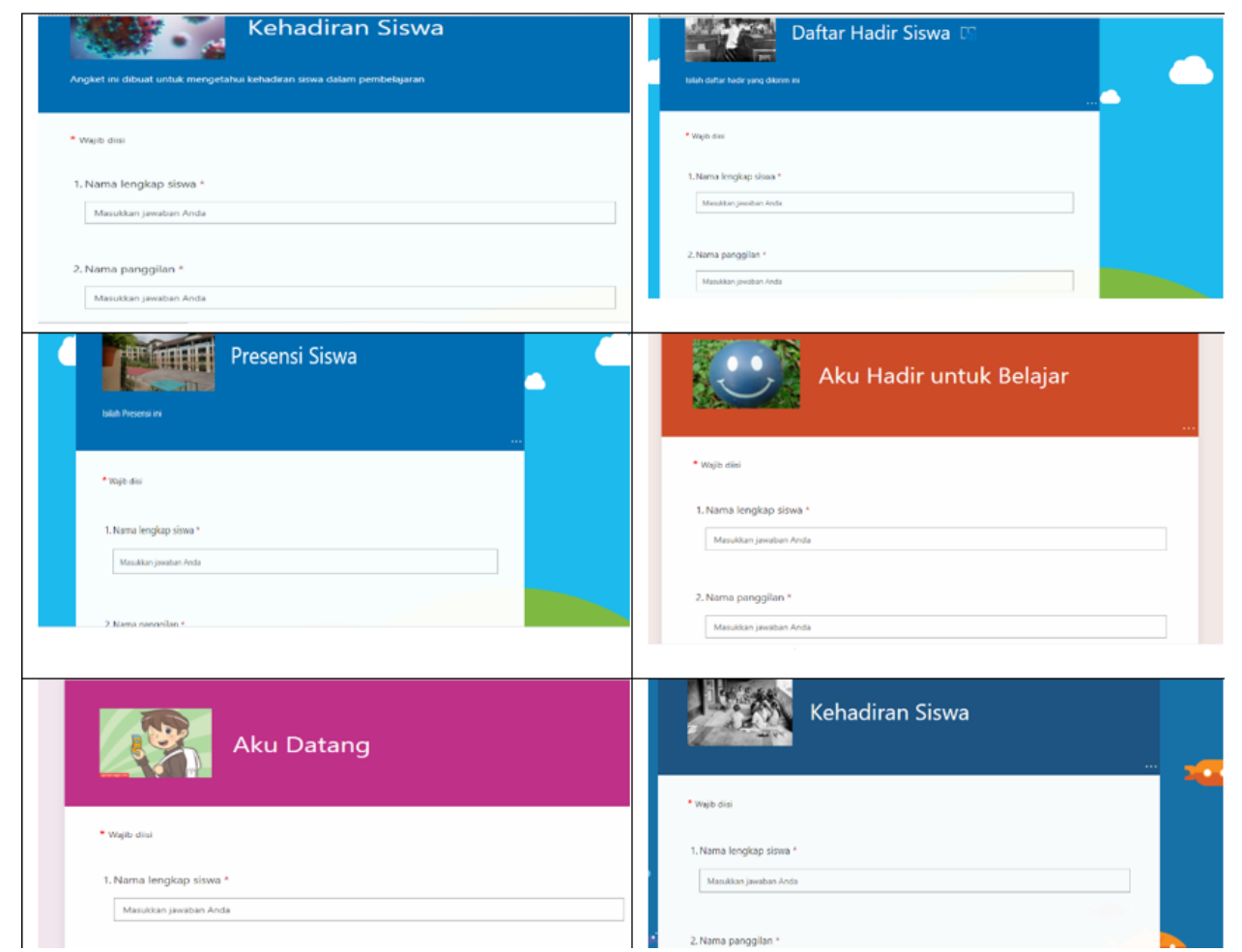

Gambar 1. forms presensi yang telah dibuat guru SD Negeri 3 Jatiluhur

Pemanfaatan fitur Forms yang telah dilakukan oleh guru-guru di SD Negeri 3 Jatiluhur sejalan dengan penelitian yang dilakukan oleh Eric Kunto Wibowo dan Anna Febrianty Setianingtyas yang berjudul Pelatihan Pemanfaatan Microsoft Office 365 bagi Pendidik di Kabupaten Klaten untuk Mewujudkan 21st Century Learning Sebuah Langkah Awal. Dalam paparannya disebutkan bahwa pemanfaatan Microsoft office 365 untuk keperluan edukatif seperti pembuatan portofolio dgital siswa, pembuatan tes dan survey daring, presentasi multikonten (audio-visual), serta penyimpanan dan berbagi materi pembelajaran di media penyimpanan awan.

b. Sway

Aplikasi Sway merupakan sarana presentasi yang dibuat secara online dan diputar secara online. Hasil presentasi bisa dibagikan kepada penerima menggunakan link yang dibagikan. Di dalam laman sway telah tersedia berbagai template design yang dapat dipilih oleh pembuat. Kress dan Bezewr (dalam 
Khoirul Huda 2017) juga menyatakan bahwa Sway merupakan alat presentasi berbasis internet dengan berbagai fitur-fitur sehingga materi presentasi dijalankan dapat menggabungkan teks, gambar, video, dan suara. Sway juga merupakan salah satu bentuk multimedia yang mengombinasikan teks dengan gambar dan bentuk tertentu. Eko Lanannueardy (dalam Khoirul Huda 2017) menjelaskan bahwa cara kerja sway sama dengan power point; yang membedakannya adalah bahwa fitur pendukungnya lebih banyak, pilihan desain lebih lengkap, dan tersedia template dalam berbagai model yang dapat digabungkan dengan versi online sehingga menghasilkan tampilan kembali. Dari pendapat di atas dapat ditarik kesimpulan bahwa sway merupakan media presentasi yang dibuat oleh guru berupa penggabungan teks, gambar,audio maupun video. Sway yang di buat oleh guru dapat membantu anak untuk memahami materi pelajaran, karena juga sebagai modul elektronik.

Berdasarkan angket yang telah disebar kepada enam guru di SD Negeri 3 Jatiluhur tentang pemanfaatan Microsoft office 365, guru A, B, C, D, E, dan F menyatakan bahwa mereka telah memanfaatkan Microsoft Office 365 yaitu fitur sway. Sway dimanfaatkan dalam melakukan presentasi materi pelajaran online kapada siswa. Sway menyimpan file-file materi pelajaran. Sehingga dapat dikatakan sebagai salah satu modul pelajaran yang digunakan guru dalam kegiatan belajar mengajar.

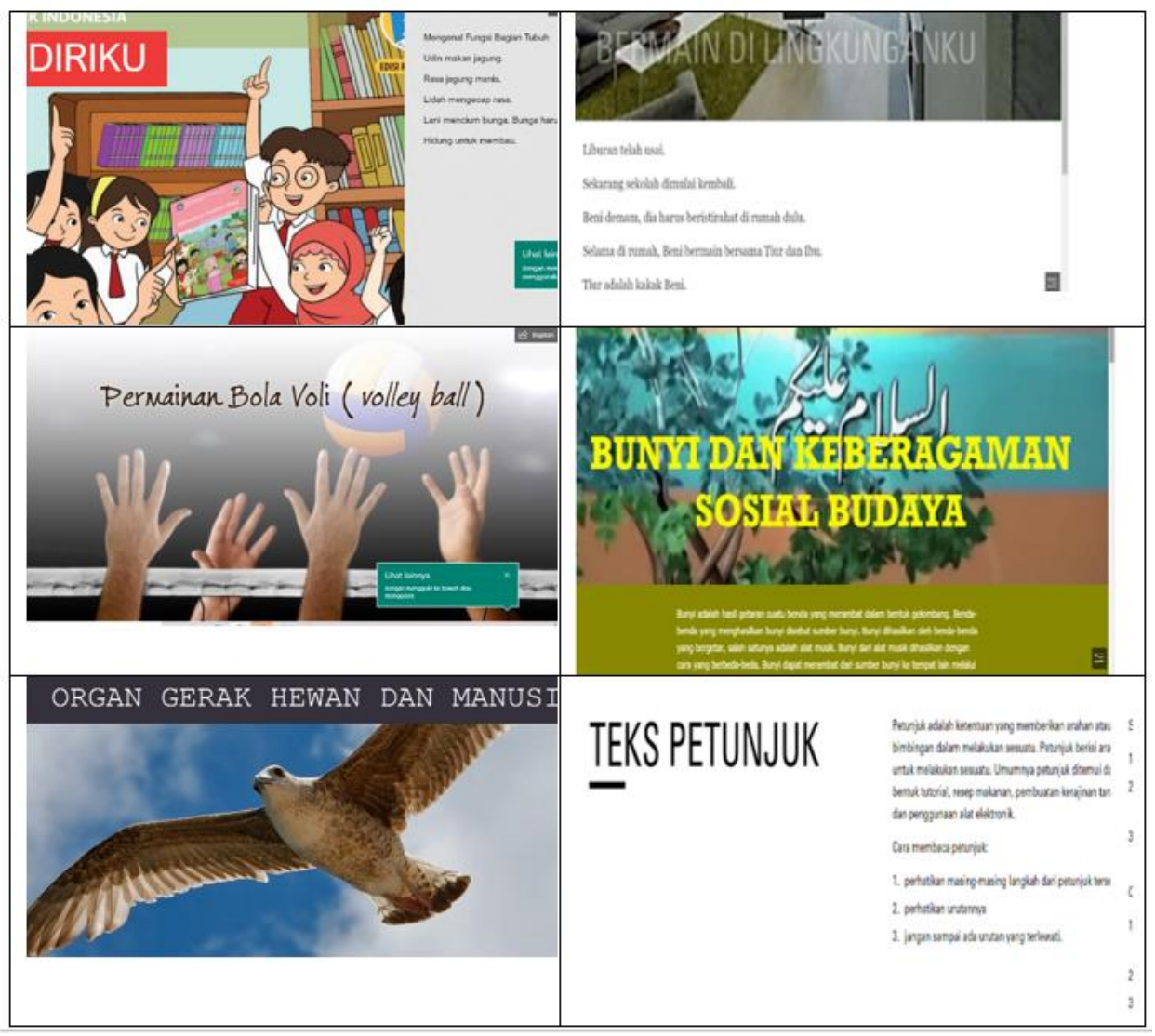

Gambar 2. Tampilan Sway Yang Telah Dibuat Guru SD Negeri 3 Jatiluhur

Pemanfaatan fitur sway yang telah dilakukan oleh guru-guru di SD Negeri 3 Jatiluhur sejalan dengan hasil penelitian Lina Widiastuti dkk (2019) yang menyatakan bahwa media pembelajaran berbasis Sway pada mata pelajaran Teknologi Informasi dan Komunikasi (TIK) dikategorikan sangat layak digunakan 
untuk pembelajaran di SMP Negeri 3 Probolinggo. Dalam penelitian yang dilakukan oleh Raharjo dkk (2020) juga disimpulkan bahwa penerapan model Problem Based Learning dengan media Sway dapat meningkatkan motivasi belajar siswa pada pembelajaran tematik Kelas III D Syuhaib Bin Jinan SD Unggulan 'Aisyiyah Bantul tahun pelajaran 2020/2021. Memang benar adanya, bahwa sway sangat membantu pembelajaran. Anak menjadi tertarik akan tayangan-tayangan di dalamnya karena berisi gabungan antara teks, gambar, audio, dan video. Sway juga dapat diputar kembali kapan saja dan dimanapun siswa berada.

\section{SIMPULAN}

Microsoft Office 365 adalah aplikasi terbaru yang bertujuan untuk mempermudah dalam berkomunikasi. Microsoft Office 365 memiliki berbagai fitur yang sangat menunjang dalam pembelajaran. Beberapa fitur tersebut diantaranya adalah Microsoft Forms dan sway. Pemanfaatan Microsoft Office 365 yang telah dilakukan oleh enam guru di SD Negeri 3 Jatiluhur adalah fitur Microsoft form dan sway. Forms digunakan sebelum melakukan pembelajaran, yaitu presensi online. Link form dikirim kepada siswa untuk diisi. Setelah diisi kemudian dikirimkan kembali kepada pembuat yaitu guru.. Sedangkan dalam pembelajaran, guru memanfaatkan fitur sway untuk melakukan presentasi materi online. Fitur Sway berfungsi sebagai media pembuatan buku digital. Materi pelajaran dapat diputar ulang oleh siswa melalui link sway yang dikirim oleh guru dimana saja dan kapan saja.

\section{DAFTAR PUSTAKA}

Dewi, W. A. F. (2020). Dampak COVID-19 terhadap Implementasi Pembelajaran Daring di Sekolah Dasar. EDUKATIF: Jurnal IImu Pendidikan, 2(1), 55-61. Diakses dari https://doi.org/10.31004/edukatif.v2i1.89

Eric Kunto, Pelatihan Pemanfaatan Microsoft Office 365 bagi Pendidik di Kabupaten Klaten untuk Mewujudkan 21st Century Learning Sebuah Langkah Awal. SNIEMAS UAD 2018. ISBN 978-602-0737-07-2

Ferdiana, R., Eka, R., \& Fauzan, I. (2013). Petunjuk Praktis Microsoft Office 365 bagi Institusi Pendidikan dan Organisasi. Yogyakarta: Lulu Publisher.

Huda, Khoirul. (2017). Pengembangan Media Pembelajaran IPS melalui Aplikasi Sway Berkonten Indis di SMP Negeri 8 Madiun. Jurnal Historia Vol.5 No.2 2017: 125141. 